Ritrýnd grein birt 25. júlí 2018

\title{
Mat nýliða á gagnsemi leiðsagnar í starfi kennara
}

\author{
María Steingrímsdóttir og Guðmundur Engilbertsson
}

\begin{abstract}
$\longrightarrow$ Abstract $>$ Um höfunda $>$ About the authors
Í greininni er fjallað um íslenskan hluta norrænnar rannsóknar á nýliðum í grunn- og framhaldsskólum - Nordment ${ }^{1}$. Rannsóknin var unnin í samstarfi fræðimanna frá háskólunum í Osló, Gautaborg, Árósum, Turku og Akureyri. Markmið rannsóknarinnar var að kanna hvernig stuðningur í skólum, skólastjórnun og skipulag innan skóla hefur áhrif á pað hvernig nýir kennarar aðlagast kennarastarfinu og hvernig peir meta eigin færni og pær aðstæður sem skólarnir bjóða peim. Pýði rannsóknarinnar var kennarar á 1.-3. starfsári eða sem höfðu nýlokið premur starfsárum. Rannsóknin var megindleg og var sami spurningalisti notaður, pýddur og staðfærður, í öllum pátttökulöndunum. Hér á landi var spurningalistinn sendur til 280 kennara, um priðjungur starfaði í framhaldsskóla og tveir priðju í grunnskóla. Niðurstöður eru byggðar á svörum 239 kennara, svarhlutfall var rúm 85\%.
\end{abstract}

Meginmarkmið pessarar greinar er að gefa innsýn í pann hluta niðurstaðnanna sem lýtur að leiðsögn nýliða í grunn- og framhaldsskólum á Íslandi. Skoðað er hvernig henni er háttað á fyrsta starfsári og hvort tengsl eru milli formlegrar leiðsagnar, tíðni funda með leiðsagnarkennara og mats nýliða á gagnsemi leiðsagnarinnar.

Helstu niðurstöður eru pær að leiðsögn hefur áhrif á starfshætti og líðan nýliða ef hún er veitt af kennara sem hefur svipaðan faglegan grunn og nýliðinn og ef peir funda reglulega saman á leiðsagnartíma. Um priðjungur pátttakenda hafði hugleitt að hætta í starfi en aðeins tíundi hluti peirra hafði pó leitað sér að öðru starfi. Ekki voru tengsl milli hugleiðinga peirra um brotthvarf og pess stuðnings sem peir fengu í starfi.

Efnisord: Nýliðar, formleg leiðsögn, óformleg leiðsögn, brotthvarf.

\section{Inngangur}

Miklar pjóðfélagslegar breytingar undanfarinna ára, svo sem fjölmenning og tækniframfarir, hafa haft sín áhrif á skólastarf og ekki síst störf kennara (Darling-Hammond, Wei, Andree, Richardson og Orpjanos, 2009; OECD, 2014). Kennarastarfið gerir bví miklar kröfur til kennara um hæfni og fagmennsku við kennslu nemenda, eins og kemur fram hjá Darling-Hammond og félögum (2009). Pau benda á að starf kennara takmarkist ekki lengur einungis við vinnu innan skólastofunnar; til að geta sinnt kennarastarfinu sem best purfi kennarinn einnig að hafa samvinnu við foreldra og forráðamenn nemenda og sérfræðinga, undirbúa kennslu í samvinnu við samkennara, ígrunda eigið starf og sinna símenntun til að efla sig faglega. •að er pví krefjandi starfsumhverfi sem mætir nýjum kennurum pegar peir koma til starfa að loknu kennaranámi, og prátt fyrir gott kennaranám er erfitt að undirbúa pá að öllu leyti fyrir margbreytileika starfsins í 
náminu sjálfu (Ingersoll, 2012). Rannsóknir hafa sýnt að mörgum nýliðum reynast pessi umskipti erfið, bæði persónulega og faglega, og að peir parfnist stuðnings við upphaf kennsluferils síns (European Commission, 2010; Hildur Hauksdóttir, 2016; Hobson, Ashby, Malderez og Tomlinson, 2009; Jonson, 2008; Le Maistre og Paré, 2010; María Steingrímsdóttir, 2007 og 2010; OECD, 2014; Ulvik, Smith og Helleve, 2009). Nýlegar rannsóknir á starfshögum nýliða beinast pví æ meira að pví hvers konar stuðning peir purfa í upphafi kennsluferilsins og hvernig best er аð veita pann stuðning fremur en hvort peir purfa hann. Markmið og tilgangur slíks stuðnings er að auðvelda nýjum kennurum aðlögun að kennarastarfinu og skólasamfélaginu svo að peim farnist vel í starfi, verði hæfari starfmenn og yfirgefi starfsvettvanginn síður eftir skamman tíma (Bartell, 2005; Darling-Hammond, 2006; European Commission, 2010; Jonsson, 2008; Russel og Russel, 2011).

Erlendar rannsóknir sýna að brottfall nýrra kennara er talsvert og í bandarískum rannsóknum má sjá að allt að helmingur kennara yfirgefur starfið á fyrstu fimm árunum, en pað er rakið til neikvæðrar reynslu í starfi (Darling-Hammond, 2003; Ingersoll og Strong, 2011; Le Maistre og Paré, 2010). Í skýrslu UNESCO Institute of Statistics (2009) um pörf á nýliðum í kennslu kom fram að tölur bentu til pess að helmingur pjóða heims teldi pörf á að fjölga kennurum til að fullnægja kennarapörf grunnskólabarna fyrir árið 2015. Par er ekki einungis um að ræða pau lönd sem oft er talað um sem próunarlönd heldur einnig lönd í Vestur-Evrópu og Bandaríkin. Í skýrslu Teaching and Learning International Survey (TALIS) (OECD, 2014) kemur fram að í peim löndum sem TALIS-rannsóknin nær til, par sem Ísland er eitt pátttökulanda, sé meðalaldur kennarastéttarinnar að hækka og til að forðast kennaraskort sé pví mikilvægt að styðja vel við bakið á nýliðum í kennarastétt. İ niðurstöðum TALIS segir að meðalaldur starfandi kennara á Íslandi hafi hækkað frá fyrri rannsókn TALIS árið 2008. Í rannsókninni frá árinu 2014 má sjá að kennarar undir prjátíu ára aldri hér á landi voru 6\% af starfandi grunnskólakennurum, en árið 2008 voru peir 13\%. Ennfremur kemur fram í sömu rannsókn að töluvert fjölgar í peim hópi kennara sem nálgast eftirlaunaaldurinn. Sama próun virðist vera hvað varðar nýliðun í stéttinni í öðrum löndum sem TALIS-rannsóknin nær til bví að í skýrslu sömu aðila frá árinu 2008 voru 13\% kennara í pátttökulöndunum undir 30 ára aldri, en voru árið 2014 tæp 10\% (OECD, 2014).

Hér á landi gæti fleira komið til en að framan greinir sem bendir til yfirvofandi kennaraskorts. Í kjölfar breytinga á lögum um menntun og ráðningu kennara og skólastjórnenda við leikskóla, grunnskóla og framhaldsskóla (nr. 87/2008) hafa færri kennarar brautskráðst frá kennaramenntastofnunum síðustu ár en ádur. Í rannsókn Helga Eiríks Eyjólfssonar og Stefáns Hrafns Jónssonar (2017) á nýliðun í kennarastarfi kemur fram að hún nær ekki að vega upp á móti peim fjölda kennara sem hættir störfum sökum aldurs. Miðað við pessar upplýsingar er fyrirsjáanlegt að innan fárra ára stefnir í kennaraskort pegar kennarar hverfa frá kennslu vegna aldurs og vegna lítillar nýliðunar í stéttinni. Pað er pví mikilvægt að athuga vel hvernig hægt er að styðja sem best pá sem hefja störf við kennslu og hvers konar stuðningur getur leitt til pess að peir ílengist í starfi og nái góðum tökum á kennarastarfinu.

Hér verður leitað svara við eftirfarandi spurningum:

- Hvernig er leiðsögn nýliða í kennslu í grunn- og framhaldsskóla háttað og hve gagnleg er hún að mati nýliðanna?

- Hefur leiðsögnin áhrif á hugleiðingar nýliða um að hverfa úr starfi?

\section{Fræðilegt baksvid}

Í pessum kafla er fjallað um fræðilegt baksvið rannsóknarinnar. Í upphafi er rætt um fyrsta starfsárið sem mótunarár fagmennsku kennara. Pá er greint frá rannsóknum á mikilvægi leiðsagnar í upphafi kennsluferils og peim áhrifum sem sú leiðsögn hefur á starfspróun og starfshætti nýliða. Loks er fjallað um formlega og óformlegra leiðsögn kennara við nýliða. 


\section{Fyrsta starfsárid}

Rannsóknir benda til pess að fyrsta ár kennara hafi mótandi áhrif á starf peirra til framtíðar, meðal annars á skilvirkni, starfsánægju og bað hversu lengi peir endast í starfi (Bartell, 2005; Darling-Hammond, 2003; Ingersoll og Strong, 2011). Pegar nýir kennarar fá litla aðstoð og peir eru látnir afskiptalausir í starfi sínu kemur pað niður á hæfni peirra og pörfum nemenda. Hætta er á bví að álag í starfi verði peim erfitt og geti valdið peim óánægju með starfið, sem leiði til pess að peir yfirgefi starfið eftir stuttan tíma. Gott kennaranám eitt og sér dugir skammt ef nýliðinn fær ekki nægjanlega fræðslu og bjálfun í mikilvægum páttum kennarastarfsins í tengslum við starfsvettvanginn sjálfan og slíkt er erfitt að veita fyrr en pangað er komið (Ingersoll, 2012). Fram hefur komið hjá Ingersoll og Strong (2011) að tengsl séu milli pess að nýliðar fái góðan stuðning fyrstu ár sín í kennslu, bættra kennsluhátta peirra og betri námsárangurs nemenda. Pað er pví mikið í húfi að vel takist til hvað varðar stuðning við nýliða.

Í ljósi framangreindra niðurstaðna er talið mikilvægt að skólar stuðli að starfsumhverfi sem auðveldar nýjum kennurum upphaf kennslunnar með pað að markmiði að aðstoða pá við að aðlagast starfinu, að mæta peim kröfum sem felast í kennarastarfinu og auka starfshæfni peirra og skuldbindingu við starfið (European commission, 2010; Feiman-Nemser, 2003; Hammerness, Darling-Hammond og Brandsford, 2005; Kemmis, Heikkinen, Fransson, Aspfors og Edwards-Groves, 2014; María Steingrímsdóttir, 2007; Smith og Ingersoll, 2004; Sundli, 2007). Feiman-Nemser (2003) heldur pví fram að formlegt innleiðingarferli (e. induction program) innan skólanna geti stuðlað að pví nýir kennarar nái fyrr tökum á kennarastarfinu en ella.

Í nokkrum löndum, svo sem Noregi og ýmsum ríkjum Bandaríkjanna, hefur verið bundið ílög og reglugerðir að nýliðar skuli fá leiðsögn á fyrsta starfsári (Jonson, 2008; Smith og Ulvik, 2010). I mörgum löndum er nú farið að leggja áherslu á leiðsögn og innleiðingu nýrra kennara í kennarastarfið og hafa ýmsar leiðir verið farnar í pví skyni, allt frá pví að byggja innleiðingu og stuðning á sjálfboðaframlagi samkennara til kerfisbundinnar leiðsagnar sem sums staðar lýkur með pví að nýliðar purfa að gangast undir hæfnispróf og jafnvel fá peir ekki starfsleyfi fyrr en peir hafa staðist pað (Fransson og Gustafsson, 2008). Einnig hefur félagastuðningur reynst nýliðum vel, t.d. par sem myndaðir hafa verið hópar kennara með mislanga kennslureynslu til að ræða við og styðja nýliðann (Heikkinen, Joikinen og Tynjälä, 2012). Pá heldur Cherubini (2009) pví fram að í peim skólum sem leggja áherslu á uppbyggingu faglegs námssamfélags sé líklegra að félagastuðningur sé innbyggður í skólamenningu og styðji par með nýliða sem koma til starfa.

\section{Áhrif leiðsagnar}

Ingersoll (2012) hefur tekið saman rannsóknir á áhrifum mismunandi forms innleiðingar fyrir nýja kennara (e. induction programs) í Bandaríkjunum og á hvaða pætti í starfi kennara góð leiðsögn hefur helst áhrif. Niðurstöður peirrar samantektar leiða í ljós að markviss leiðsögn hefur jákvæð áhrif á starfsánægju og skuldbindingu við starfið og skólum helst betur á kennurum. Enn fremur benda niðurstöðurnar til pess að peir sem fái stuðning ráði betur við marga mikilvæga pætti kennarastarfsins, svo sem að halda nemendum að verki, gera raunhæfar kennsluáætlanir og að nota góða spurningatækni í kennslu sinni. Peir hafi einnig betri tök á bekkjarstjórnun og séu færari í að laga kennsluna að mismunandi getu og áhuga nemenda. Síðast en ekki síst sýna flestar rannsóknir að nemendur peirra nýliða sem fá markvissan stuðning ná betri námsárangri en nemendur peirra sem ekki njóta viðlíks stuðnings (Ingersoll, 2012).

Í samantekt Ingersoll (2012) á nýliðarannsóknunum kemur fram að góður árangur af stuðningi byggist á pví hversu fjölbreyttur hann er, hversu lengi nýliðar njóta hans og hversu aðgengilegur stuðningurinn er nýliðunum. Par kemur einnig fram að samstarf við samkennara, t.d. við undirbúning og skipulagningu kennslunnar, sé nýliðanum mikilvægt. Fram kemur að bestur árangur næst ef leiðsögnin er frá kennara sem kennir sömu námsgrein eða námssvið og nýliðinn. Rannsóknir Desimone o.fl. (2014) benda til pess að pegar nýliði fær leiðsögn frá peim sem pekkir 
vel til sömu námsgreinar og nýliðinn kennir byggist samræða milli peirra á gagnkvæmri pekkingu á viðfangsefnum, pekkingu á viðbrögðum við námsframvindu nemenda og rökræðum um kennsluaðferðir sem hæfa nemendum og námsefni. Рað rímar vel við pá skoðun Jonsson (2008) að peir sem sinni leiðsögn purfi að geta miðlað árangursríkum kennsluaðferðum sem peir sjálfir hafi góð tök á, hafi góða pekkingu á námskrá og inntaki námsefnis, geti verið góðir hlustendur og hafi gott vald á spurningatækni til að leiða samræður (e. dialogue). Johnson og Birkeland (2003) halda pví fram að ekki sé nægjanlegt að veita aðeins stuðning í upphafi starfsferils heldur purfi hann að standa nýliðum til boða í pað minnsta allt fyrsta starfsárið en draga megi úr honum á öðru starfsári. Desimone og félagar (2014) benda á að miklu varði um árangur leiðsagnar og pað hvernig nýliðar meti leiðsögnina hversu oft leiðsagnarkennarar (mentorar) og nýliðar eigi formleg samskipti. Ragnhildur Bjarnadóttir (2015) undirstrikar petta pegar hún talar um mikilvægi funda pess sem veitir leiðsögn og pess sem piggur hana. Á slíkum fundum purfi ekki aðeins að ræða verklega pætti starfsins heldur einnig að taka á siðrænum, huglægum og félagslegum hliðum pess. Hún kallar pessa fundi leiðsagnarfundi og segir að mikilvægt sé að fastsetja tíma fyrir pá í dagskipan peirra sem að málum koma og að undirbúningur fundanna purfi að vera góður, skapa purfi hagstæðar aðstæður og ætla purfi góðan tíma í fundina.

\section{Formleg - óformleg leiðsögn}

Pó að mismunandi leiðir hafi verið farnar til pess að styðja nýja kennara segirJonsson (2008) að par sem formleg leiðsögn hafi verið veitt hafi yfirleitt verið stuðst við ákveðnar innleiðingaráætlanir. Pess konar innleiðing hefur falið í sér pað sem kalla mætti formlega leiðsögn par sem einn ákveðinn leiðsagnarkennari (mentor), sem valinn er af skólastjórnendum, er ábyrgur fyrir leiðsögn nýja kennarans. Rannsóknir á nýliðum (Desimone o.fl., 2014; Johnson og Birkeland, 2003) hafa pó sýnt fram á að peir fá einnig leiðsögn frá öðrum innan skólans en peim sem formlega eru skipaðir til að sinna pví verkefni. Par er átt við samstarfsfólk sem nýliðarnir sjálfir kjósa að leita til með atriði sem peir parfnast aðstoðar við. Pess konar aðstoð hefur verið kölluð óformleg leiðsögn og er hún talin pýðingarmikil fyrir nýliða með tilliti til pess hvernig peim vegnar fyrstu árin (Desimone o.fl., 2014).

Eðli málsins samkvæmt er erfitt að bera í senn saman gagnsemi formlegrar og óformlegrar leiðsagnar hjá sömu kennurum, pó svo að rannsóknir hafi verið gerðar á pessu sínu í hvoru lagi. Desimone og félagar (2014) benda á að oft sé munur á formlegri og óformlegri leiðsögn lítill en engu að síður sé óformleg leiðsögn mikilvæg og best sé að tvinna hana saman við formlega leiðsögn í skólum. Pví til stuðnings segja pau að óformleg leiðsögn geti mætt sértækum páttum í kennarastarfinu sem formleg og skipuleg leiðsögn nái síður til. Par má nefna gott aðgengi að samkennara par sem nýliðar geti leitað til samkennara með hluti sem parfnast úrlausnar eða endurgjafar fljótt og vel. Sem dæmi um pað nefna Desimone og félagar (2014) uppákomur eða atvik varðandi bekkjarstjórnun, ýmislegt sem tilheyrir framkvæmd kennslu, foreldrasamstarf og tilfinningalegan stuðning í daglegum störfum kennarans og persónulegar parfir nýliðans. Hins vegar telja pau að formlegur leiðsagnarkennari eigi að veita dýpri og faglegri endurgjöf á undirbúning, framkvæmd og mat kennslunnar. Par taka pau í sama streng og Bartell (2005), sem segir að formleg leiðsögn eigi að fela í sér samskipti sem leiða til breytts atferlis, aukinnar víðsýni, dýpri skilnings, aukinnar sjálfspekkingar og aukins starfsproska peirra sem taka pátt í henni. Pá segir Tolhurst (2010) að nauðsynlegt sé fyrir pá sem veita leiðsögn að geta greint hvers konar stuðnings sé pörf í hverju tilfelli og hann leggur áherslu á að nýliðinn fái styðjandi endurgjöf á starf sitt sem byggist á samræðu (e. dialogue). Pannig fái kennarar aðstoð við að ígrunda starf sitt og íhuga hvernig til hefur tekist og draga lærdóm af. Enn fremur kemur fram hjá Tolhurst að jafnvægi purfi að vera í leiðsögn pannig að stutt sé bæði við persónulegan stíl og kennsluhætti kennara og efla purfi skilning peirra á pví hvað árangursrík kennsla sé. Undir petta taka Van Esch og Tillema (2015) sem segja að samræður milli aðila purfi að vera krefjandi, styðjandi og lausnamiðaðar. 
Í rannsóknum Smith (2015) og Helleve, Danielsen og Smith (2015) koma fram vísbendingar um að munur sé á leiðsögn peirra sem hafa leiðsagnarmenntun og peirra sem enga menntun hafa á pessu sviði. Munurinn komi helst fram í pví að peir sem eru vel undirbúnir fyrir leiðsagnarstarfið viti hvernig og hvers vegna purfi að leggja áherslu á ýmsa pætti, t.d. séu peir meðvitaðri um ábyrgð sína á faglegri próun kennara og séu færari um að ýta undir ígrundun peirra sem leiðsögn piggja. Pær segja pví mikilvægt að peir sem leiðsögn veiti fái pjálfun í pví að haga leiðsögn pannig að hún verði sem árangursríkust. Niðurstöður peirra eru pví pær að allir nýliðar purfi og eigi að fá stuðning og best sé að sá stuðningur sé skipulagður pannig að hann sé bæði formlegur og óformlegur og innbyggður í menningu hvers skóla.

\section{Aðferd}

Rannsóknin var megindleg, byggð á gögnum úr spurningalista til nýrra kennara í grunn- og framhaldsskólum á Islandi. Rannsóknin er hluti af rannsóknarverkefninu NORDMENT par sem spurningalisti, pýddur og staðfærður, var lagður fyrir í Danmörku, Finnlandi, Noregi, á Íslandi og í Svípjód. Spurningalistinn snerist um pætti eins og öryggi i starfi, stuðning við próunarstarf, sjálfstaði i starfi, skuldbindingu, starfsatferli, ásetning um að hatta, stjórnun starfsaðsteðna, starfshlutverk, tímapressu, endurgjöf við frammistöðu, traust, stuðning frá stofnun, pekkingu, viðhorf til sí- og endurmenntunar og óformlega og formlega leiðsögn. Í greininni verður rýnt í pætti er varða formlega leiðsögn á fyrsta ári í starfi og óformlegan stuðning frá skólanum sem stofnun, stjórnendum og samkennurum.

\section{Pátttakendur}

Par sem ekki liggja fyrir á einum stað upplýsingar um nýliða í starfi var leitað til Skólastjórafélags Íslands sem gaf upp netfangalista skólastjóra í grunn- og framhaldsskólum og peir síðan beðnir að gefa upp netföng kennara á sínu fyrsta til priðja starfsári (eða sem höfðu nýlokið premur árum). Skólastjórarnir gáfu upp nöfn og netföng 280 kennara og voru peir í kjölfarið beðnir að svara spurningalistanum.

239 kennarar svöruðu listanum, par af voru 44 karlar (19\%) og 189 konur $(81 \%)$ og var svarhlutfall 85\%. Hlutfall kynja var breytilegt eftir skólastigi, í grunnskólanum voru tæp 85\% konur og rúm 15\% karlar en í framhaldsskólanum rúm 73\% konur en tæp 27\% karlar. Rúmur priðjungur kennaranna starfaði í framhaldsskóla $(\mathrm{n}=82)$ og um tveir priðju í grunnskóla $(\mathrm{n}=158)$. Starfsreynsla var á bilinu eitt til prjú ár og var hlutfall í hverjum hópi (á fyrsta, öðru og priðja ári í kennslu) nokkuð jafnt. Nokkrir (11\%) höfðu lokið premur árum og voru á sínu fjórða ári í kennslu pegar könnunin fór fram. Meginporri kennaranna var á aldursbilunum 31-40 ára (43\%) og 30 ára eða yngri (36\%) eða í heild tæp 80\%. Fáir voru 51 árs gamlir eða eldri (6\%).

\section{Framkvæmd og gagnavinnsla}

Í desember 2014 var netföngum kennara í grunn- og framhaldsskólum sem voru á sínum fyrstu premur árum í kennslu safnað. Spurningalistinn var lagður rafrænt (SurveyMonkey) fyrir kennarana í janúar 2015. Rannsóknin var tilkynnt til Persónuverndar og svör voru ekki rekjanleg til einstakra pátttakenda. Unnið var úr gögnum í IBM SPSS 22.0. Reiknað var kí-kvaðrat og borin saman hlutföll pegar önnur eða báðar breytur voru á nafnkvarða. Marktektarmörk voru miðuð við að p-gildi væri lægra en 0,05.

\section{Niðurstöður}

Niðurstöður úr peim páttum rannsóknarinnar sem hér er fjallað um eru settar pannig fram að fyrst verður gerð grein fyrir úrtakinu, m.a. náms- og faglegum grunni pátttakenda. Pví næst er greint frá tengslum milli formlegrar leiðsagnar, tíðni formlegra funda með leiðsagnarkennara og gagnsemi leið- 
sagnar, að mati kennara, fyrir ýmsa petti i starfi peirra. Að lokum er skoðað hvort tengsl eru milli hugleiðinga nýliða um brotthvarf úr starfi og pess hoort peir fengu leiðsögn á fyrsta starfsári eða ekki.

\section{Náms- og faglegur grunnur bátttakenda}

Meginporri pátttakenda (90\%) átti að baki priggja til fjögurra ára háskólanám á bakkalárstigi $(56 \%)$ eða meira en fjögurra ára nám á meistara- eða doktorsstigi (34\%). Pátttakendur voru beðnir að merkja við pað náms- eða fagsvið sem ætti best við um pá og var dreifing svara eftir fagsviðum nokkuð jöfn í heild pótt hún væri ólík eftir skólastigi (sjá töflu 1).

Tafla 1. Náms- eða fagsvið pátttakenda.

\begin{tabular}{lccc}
\hline Svid & $\begin{array}{c}\text { Grunnskóli } \\
(\mathbf{\%})\end{array}$ & $\begin{array}{c}\text { Framhaldsskóli } \\
(\mathbf{\%})\end{array}$ & $\begin{array}{c}\text { Heild } \\
(\mathbf{\%})\end{array}$ \\
\hline $\begin{array}{l}\text { Náttúru-/raunvísindi (stærðfræði, líffræði, efna- } \\
\text { fræði o.s.frv.) }\end{array}$ & 12 & 32 & 19 \\
$\begin{array}{l}\text { Tungumál (íslenska, norræn mál, enska, } \\
\text { franska, pýska o.s.frv.) }\end{array}$ & 16 & 23 & 19 \\
$\begin{array}{l}\text { Félagsvísindi (félagsfræði, landafræði, stjórn- } \\
\text { málafræði o.s.frv.) }\end{array}$ & 20 & 19 & 19 \\
$\begin{array}{l}\text { Listir og fagurfræði (tónlist, dans, leiklist, } \\
\text { ípróttir o.s.frv.) }\end{array}$ & 28 & 10 & 21 \\
Annað (t.d. starfsmenntun) & 26 & 16 & 22 \\
\hline
\end{tabular}

Pótt dreifingin væri tiltölulega jöfn í heild (bæði skólastig) merkti hátt í priðjungur framhaldsskólakennara við náttúruvísindasvið en aðeins 12\% grunnskólakennara. Hlutfallið snerist við pegar listir áttu í hlut. Jafnast var hlutfall grunn- og framhaldsskólakennara á sviði félagsvísinda. Peir sem merktu við möguleikann ,annað“ gáfu upp ýmis og ólík fagsvið. Oft var um verkgreinar að ræða (bæði skólastig), sérkennslu eða stuðning (bæði skólastig) og almenna bekkjarkennslu (grunnskólastig) en oftast sögðust kennarar sem merktu við annað vera yngri barna kennarar (grunnskólastig).

\section{Leiðsögn á fyrsta starfsári}

117 nýliðar af 239, eða tæp 49\%, höfðu leiðsagnarkennara á fyrsta starfsári. Hlutfallið var tiltölulega jafnt eftir skólastigi, rúm 48\% nýliða í framhaldsskóla $(\mathrm{n}=39)$ og rúm 49\% í grunnskóla (n = 78). Spurt var hvort leiðsagnarkennari peirra hefði kennt sömu námsgrein (eða námssvið) og peir og svöruðu rúm 68\% pví játandi, tæplega 20\% neitandi en 12\% peirra sögðust ekki vita pað (sjá töflu 2).

Tafla 2. Náms- eða fagsvið leiðsagnarkennaranna.

\begin{tabular}{lccc}
\hline Leiðsagnarkennari & $\begin{array}{c}\text { Grunnskóli } \\
(\mathbf{\%})\end{array}$ & $\begin{array}{c}\text { Framhaldsskóli } \\
(\mathbf{\%})\end{array}$ & $\begin{array}{c}\text { Heild } \\
(\mathbf{\%})\end{array}$ \\
\hline Með sama námssvið/námsgrein og nýliði & 61,5 & 82,1 & 68,4 \\
Með annað námssvið/námsgrein en nýliði & 23,1 & 12,8 & 19,7 \\
Veit ekki & 15,4 & 5,1 & 12,0 \\
\hline
\end{tabular}


Eins og tafla 2 sýnir var nokkur munur eftir skólastigi. Meðan rúm 82\% nýliða í framhaldsskóla sögðu að leiðsagnarkennari peirra hefði kennt sömu námsgrein sögðu rúm $62 \%$ nýliða í grunnskóla pað sama. Peir sem voru óvissir í peim efnum (merktu við veit ekki) voru nær eingöngu nýliðar í grunnskóla.

Afstaða nýliðanna til mikilvægis pess að leiðsagnarkennari kenndi sömu námsgreinar (eða námssvið) á kvarðanum 1 (gagnslaus) til 6 (mjög gagnlegur) var frekar afdráttarlaus. Að meðaltali gáfu peir pví 5,2 stig af 6 mögulegum. Nokkur munur var á svörum eftir skólastigi, 5,1 hjá pátttakendum í grunnskóla en 5,4 í framhaldsskóla. Peir sem kenndu í framhaldsskóla töldu pað mikilvægara en peir sem kenndu í grunnskóla að leiðsagnarkennari peirra hefði svipaðan faglegan bakgrunn eða kenndi sambærilegar greinar og peir.

\section{Tíðni formlegra funda kennara og leiðsagnarkennara}

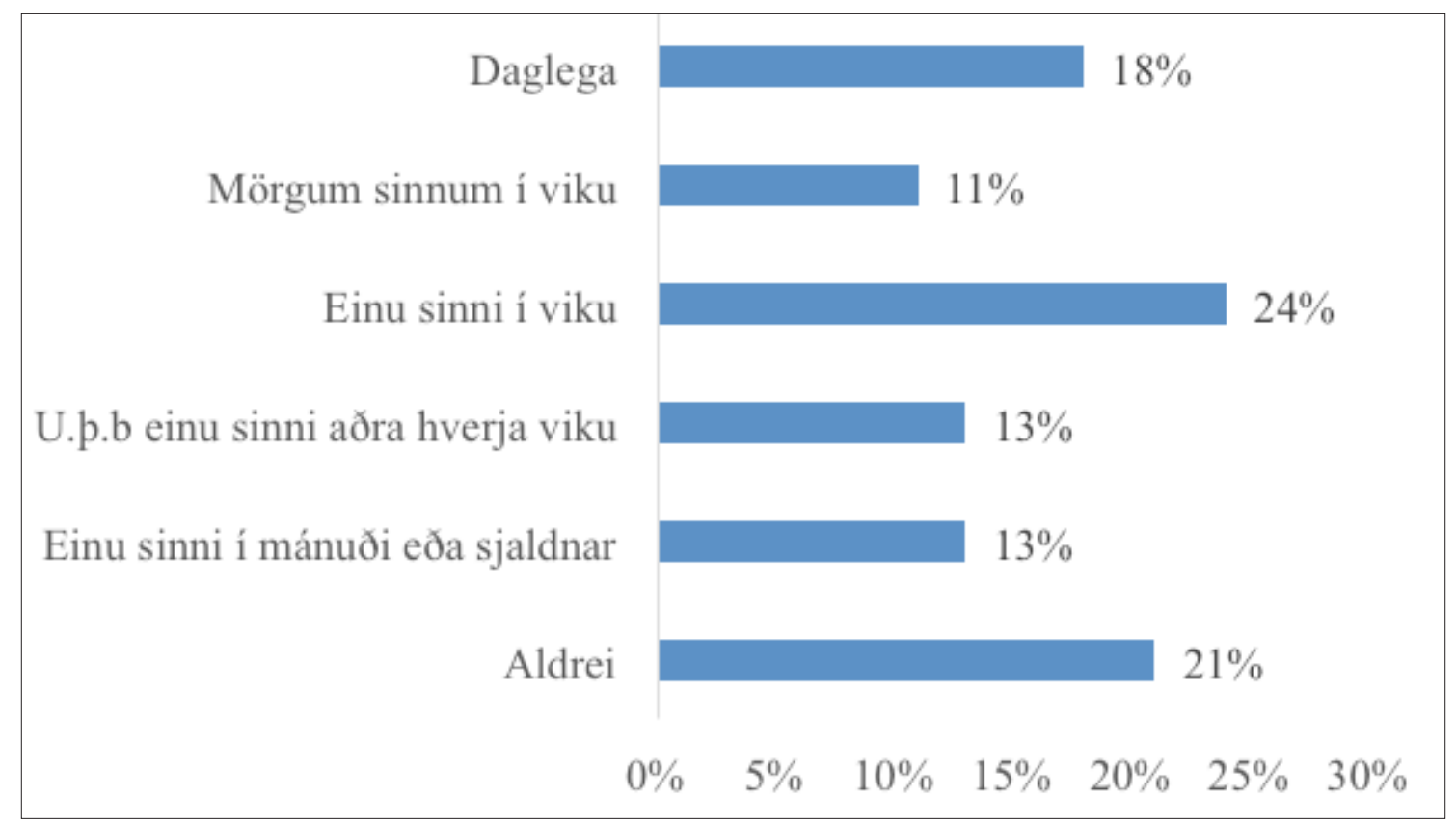

Mynd 1. Tíðni formlegra funda í leiðsögn.

Spurt var um tíðni formlegra funda kennara og leiðsagnarkennara og voru nokkrir möguleikar uppgefnir, allt frá pví að funda aldrei til pess að funda daglega (sjá mynd 1).

Rúmlega fimmtungur kennara sagðist aldrei hafa hitt leiðsagnarkennara sinn á formlegum fundum og samtals sagðist rúmur priðjungur kennara hafa hitt leiðsagnarkennara sinn aðeins einu sinni í mánuði eða sjaldnar. Rúmur helmingur sagðist hins vegar hafa hitt leiðsagnarkennarann einu sinni í viku eða oftar. Ekki var breytileiki í svörum eftir skólastigi, faglegum bakgrunni nýliða eða pví hvort leiðsagnarkennari peirra var með svipaðan bakgrunn og peir eða ekki. 


\section{Mat pátttakenda á gagnsemi leiðsagnar}

Mat á pví hve gagnlegur stuðningur leiðsagnarkennara væri á kvarðanum 1 (alveg gagnslaus) til 6 (mjög gagnlegur) var að meðaltali um 4,03 til 4,79, eftir pví hvaða pátt var spurt um (sjá töflu 3).

Tafla 3. Meðaltal mats kennara á gagnsemi leiðsagnar (á bilinu 1-6) eftir skólastigi.

\begin{tabular}{lccc}
\hline Pættir & $\begin{array}{c}\text { Grunn- } \\
\text { skóli }\end{array}$ & $\begin{array}{c}\text { Framhalds- } \\
\text { skóli }\end{array}$ & Heild \\
\hline Próun kennslu sem virkar & 4,03 & 4,45 & 4,20 \\
Taka á krefjandi aðstæðum í kennslustofunni & 4,45 & 4,45 & 4,45 \\
Mat á vinnu nemenda & 4,16 & 4.62 & 4,33 \\
Ráðgjöf um hvernig hátta má kennslu & 4,23 & 4,83 & 4,45 \\
Fá upplýsingar um hagnýta pætti sem nýráðinn & 4,56 & 4,79 & 4,64 \\
kennari veltir fyrir sér & & & \\
\hline
\end{tabular}

Taflan sýnir að nýliðar í framhaldsskólum gáfu stuðningi leiðsagnarkennara hærri einkunn en nýliðar í grunnskólum fyrir fjóra af fimm gefnum páttum. Skoðað var hvort marktækur breytileiki væri í einkunnagjöf eftir kyni, menntunargrunni og meginnámssviði í kennslu en svo reyndist ekki vera.

Pegar afstaða kennara til gagnsemi leiðsagnar var skoðuð í ljósi tíðni formlegra leiðsagnarfunda kom í ljós mynstur (sjá töflu 4).

Tafla 4. Mat pátttakenda á gagnsemi leiðsagnar eftir tíðni formlegra leiðsagnarfunda.

\begin{tabular}{lccc}
\hline Pættir og hlutfall einkunna í mati, & $\begin{array}{c}\text { Fundad vikulega } \\
\text { eda oftar }\end{array}$ & $\begin{array}{c}\text { Fundad sjaldnar } \\
\text { en vikulega }\end{array}$ & Heild \\
$\begin{array}{l}\text { á annars vegar bilinu 0-3 og hins } \\
\text { vegar 4-6 }\end{array}$ & $\%$ & $\%$ & $\%$ \\
\hline
\end{tabular}

Próun kennslu sem virkar

Mat á bilinu 0-3

$8,6 \quad 23,5$

32,1

Mat á bilinu 4-6

38,3

29,6

67,9

Taka á krefjandi aðstæðum í kennslustofu

Mat á bilinu 0-3

22,2

27,2

Mat á bilinu 4-6

42,0

30,9

Mat á vinnu nemenda

Mat á bilinu 0-3

$$
8,8
$$

21,3

30,0

Mat á bilinu 4-6

38,8

31,3

Ráðgjöf um hvernig hátta má kennslu

Mat á bilinu 0-3

21,0

24,7

Mat á bilinu 4-6

43,2

32,1

75,3

Fá upplýsingar um hagnýta pætti

Mat á bilinu 0-3

$$
3,8
$$

20,5

24,4

Mat á bilinu 4-6

42,3

33,3

75,6


Nýliðar sem funduðu vikulega eða oftar með leiðsagnarkennara sínum gáfu mun síður einkunnina 3 eða lægra fyrir gagnsemi leiðsagnar en peir sem funduðu sjaldnar en vikulega. Vel innan við 10\% peirra sem funduðu vikulega eða oftar gáfu einkunnina 3 eða lægri einkunn, en rúmur fimmtungur peirra sem fundaði sjaldnar. Í öllum tilvikum sýndi greining (kí-kvaðrat) að munurinn væri tölfræðilega marktækur $(\mathrm{p}<0,05)$.

Skoðað var hvort tengja mætti tíðni funda við bakgrunn leiðsagnarkennara (grein/námssvið), sjá töflu 5.

Tafla 5. Tíðni funda nýliða og leiðsagnarkennara eftir grein/námssviði leiðsagnarkennara.

\begin{tabular}{lccc}
\hline & \multicolumn{3}{c}{ Kennari kennir sömu grein/námssvið } \\
\hline & Já & Nei & Veit ekki \\
Vikulega eða oftar & $84 \%$ & $16 \%$ & $0 \%$ \\
Sjaldnar en vikulega & $64 \%$ & $18 \%$ & $18 \%$ \\
Alls & $73 \%$ & $17 \%$ & $10 \%$ \\
\hline
\end{tabular}

Taflan sýnir að nýliðar og leiðsagnarkennari funduðu frekar vikulega eða oftar pegar peir voru með svipaðan bakgrunn (grein/námssvið). Sá munur var marktækur $\left(\chi^{2}(2, \mathrm{~N}=88)=8,12, p=\right.$ 0,017). Peir sem sögðust ekki vita hvort leiðsagnarkennari væri með bakgrunn í grein eða námssviði nýliðans (aðallega í grunnskóla) sögðu allir að fundað hefði verið sjaldnar en vikulega.

\section{Tengsl leiðsagnarfunda og upplifunar nýliða á stuðningi frá skólanum og samkennurum}

Svör nýliðanna við ýmsum spurningum um stuðning skóla og samstarfsmanna við nýliða í starfi voru skoðuð í ljósi skólastigs, leiðsagnar og tíðni formlegra funda með leiðsagnarkennara á fyrsta ári. Spurt var hvort skólanum væri umhugað um líðan nýliða og hvort hann veitti aðstoð pegar nýliði pyrfti á að halda (sjá töflu 6).

Tafla 6. Skólanum er umhugað um líðan mína og veitir aðstoð pegar ég parf á henni að halda.

\begin{tabular}{lcccccc}
\hline & $\begin{array}{c}\text { Algerlega } \\
\text { ósammála }\end{array}$ & $\begin{array}{c}\text { Ad } \\
\text { mestu } \\
\text { ósammála }\end{array}$ & $\begin{array}{c}\text { Meira } \\
\text { ósammála } \\
\text { en sammála }\end{array}$ & $\begin{array}{c}\text { Meira } \\
\text { sammála } \\
\text { en ósammála }\end{array}$ & $\begin{array}{c}\text { Að mestu } \\
\text { sammála }\end{array}$ Algerlega \\
sammála
\end{tabular}

Í heild voru 87\% nýliðanna sammála pví að skólanum væri umhugað um líðan peirra og að hann veitti peim stuðning pegar peir pyrftu á honum að halda. Ekki var munur eftir skólastigi eða pví hvort nýliðar fengju leiðsögn eða ekki á sínu fyrsta starfsári, en pegar skoðað var hvort tíðni funda nýliða og leiðsagnarkennara skipti máli kom í ljós marktækur munur. Peir sem funduðu vikulega eða oftar með leiðsagnarkennara sínum (um helmingur nýliða) voru pví frekar sammála en aðrir að skólanum væri umhugað um líðan peirra $\left(\chi^{2}(5, \mathrm{~N}=101)=11,92, p=0,036\right)$ og að hann veitti peim aðstoð í $\operatorname{starfi}\left(\chi^{2}(5, \mathrm{~N}=101)=13,58, p=0,019\right)$. 
Einnig var litið til stuðnings annarra kennara en leiðsagnarkennara við nýliða í starfi (tafla 7).

Tafla 7. Stuðningur annarra kennara en leiðsagnarkennara við nýliða í starfi.

\begin{tabular}{|c|c|c|c|c|c|c|}
\hline & Enginn & Fáeinir & $\begin{array}{c}\text { U.p.b. } \\
\text { helmingur }\end{array}$ & $\begin{array}{c}\text { Nokkud } \\
\text { margir }\end{array}$ & Flestir & $\begin{array}{l}\text { Nastum } \\
\text { allir }\end{array}$ \\
\hline $\begin{array}{l}\text { Hve margir kennarar við } \\
\text { pennan skóla hjálpa nýlið- } \\
\text { um í kennslu að gera sitt } \\
\text { besta? }\end{array}$ & $5 \%$ & $32 \%$ & $10 \%$ & $16 \%$ & $23 \%$ & $15 \%$ \\
\hline $\begin{array}{l}\text { Hve margir kennarar við } \\
\text { pennan skóla styðja nýliða í } \\
\text { starfi pegar peir eiga í erfið- } \\
\text { leikum með nemendur? }\end{array}$ & $4 \%$ & $25 \%$ & $13 \%$ & $17 \%$ & $26 \%$ & $15 \%$ \\
\hline $\begin{array}{l}\text { Hve margir kennarar við } \\
\text { pennan skóla bregðast við } \\
\text { pegar nýliðar í kennslu eiga } \\
\text { í samskiptavanda við nem- } \\
\text { endur? }\end{array}$ & $4 \%$ & $31 \%$ & $9 \%$ & $17 \%$ & $24 \%$ & $15 \%$ \\
\hline $\begin{array}{l}\text { Hve margir kennarar við } \\
\text { pennan skóla hjálpa nýlið- } \\
\text { um í kennslu? }\end{array}$ & $4 \%$ & $34 \%$ & $8 \%$ & $16 \%$ & $22 \%$ & $16 \%$ \\
\hline
\end{tabular}

Um og yfir priðjungur nýliðanna (misjafnt eftir páttum) taldi að enginn eða fáeinir kennarar veittu nýliðum stuðning í starfi. Hátt í 40\% peirra töldu að flestir eða næstum allir kennarar skólans styddu pá í starfi. Ekki var munur eftir skólastigi eða pví hvort nýliðar fengu leiðsögn eða ekki á sínu fyrsta starfsári, en pegar skoðað var hvort tíðni funda nýliða og leiðsagnarkennara skipti máli kom í ljós marktækur munur er varðar alla pættina, peir sem funduðu vikulega eða oftar með leiðbeinanda sínum upplifðu marktækt meiri stuðning kennara í skólum sínum við nýliða í starfi, sjá töflu 8.

Tafla 8. Tengsl formlegra funda nýliða og leiðsagnarkennara og upplifunar á stuðningi.

\begin{tabular}{|c|c|}
\hline $\begin{array}{l}\text { Peir sem hittu leiðsagnarkennara sinn vikulega eða } \\
\text { oftar voru: }\end{array}$ & Kí-kvaðrat \\
\hline $\begin{array}{l}\text {... líklegri en aðrir til að segja að flestir eða allir kennarar við } \\
\text { skólann reyndu að hjálpa nýliðum í kennslu }\end{array}$ & $\begin{array}{l}\left(\chi^{2}(5, \mathrm{~N}=97)=27,10\right. \\
p<0,001)\end{array}$ \\
\hline $\begin{array}{l}\text {... líklegri en aðrir til að segja að flestir eða allir kennarar við } \\
\text { skólann styddu nýliða í kennslu pegar peir ættu í erfiðleikum með } \\
\text { nemendur }\end{array}$ & $\begin{array}{l}\left(\chi^{2}(5, N=101)=25,31\right. \\
p<0,001)\end{array}$ \\
\hline $\begin{array}{l}\text {... líklegri en aðrir til að segja að flestir eða næstum allir kennarar } \\
\text { við skólann hjálpuðu nýliðum í kennslu að gera sitt besta }\end{array}$ & $\begin{array}{l}\left(\chi^{2}(5, N=101)=27,16\right. \\
p<0,001)\end{array}$ \\
\hline $\begin{array}{l}\text {... líklegri en aðrir til að segja að flestir eða allir kennarar við } \\
\text { skólann brygðust við pegar nýliðar í kennslu ættu í samskipta- } \\
\text { vanda við nemendur }\end{array}$ & $\begin{array}{l}\left(\chi^{2}(5, \mathrm{~N}=97)=25,59\right. \\
p<0,001)\end{array}$ \\
\hline
\end{tabular}




\section{Brotthvarf}

Skoðað var hvort nýliðarnir hefðu hug á að hætta í starfi (sjá töflu 9).

Tafla 9. Hugleiðingar um að hætta í starfi.

\begin{tabular}{lcc}
\hline & $\begin{array}{c}\text { Sammála } \\
(\mathbf{\%})\end{array}$ & $\begin{array}{c}\text { Ósammála } \\
(\mathbf{\%})\end{array}$ \\
\hline Ég velti pví alvarlega fyrir mér að skipta um starf. & 27 & 73 \\
Ég hugsa oft um að hætta í núverandi starfi mínu. & 22 & 79 \\
Um leið og ég finn annað starf vil ég hætta að starfa við pennan & 15 & 85 \\
skóla. & & \\
Ég leita með skipulegum hætti að nýju starfi. & 11 & 89 \\
\hline
\end{tabular}

27\% pátttakenda sögðust hafa velt pví alvarlega fyrir sér að skipta um starf. Rúmur helmingur peirra sagðist myndu hætta við pann skóla sem peir störfuðu í um leið og peir fyndu annað starf og 11\% sögðust leita með skipulegum hætti að nýju starfi. Ekki var marktækur munur á svörum eftir skólastigi eða pví hvort peir fengu leiðsögn á sínu fyrsta ári eða ekki. Ekki var heldur marktækur munur hjá peim hópi sem fékk leiðsögn eftir tíðni funda með leiðsagnarkennara eða faglegum bakgrunni leiðsagnarkennara (námsgrein/námssviði).

\section{Umræða}

Eins og fram kemur í ágripi er meginmarkmið greinarinnar að gefa innsýn í pað hvernig leiðsögn nýliða sem fá skipaðan leiðsagnarkennara í grunn- og framhaldsskólum er háttað á fyrsta kennsluári, með pví að skoða tengsl milli formlegrar leiðsagnar, tíðni formlegra funda og gagnsemi leiðsagnar fyrir ýmsa pætti í starfi peirra að mati pátttakenda.

Hér eru niðurstöður teknar saman og ræddar og tengdar við fræðilegt baksvið. Fyrst er fjallað um pátttakendur í rannsókninni og hversu margir af fyrsta árs kennurum fengu leiðsagnarkennara, pá um umgjörð og framkvæmd peirrar leiðsagnar og bví næst um áhrif leiðsagnarinnar á ýmsa pætti sem tengjast starfi pátttakenda. Að lokum er fjallað um pað hvort tengsl eru milli hugleiðinga pátttakenda um brotthvarf úr starfi og leiðsagnar.

Munur var á svörum eftir pví hvort pátttakendur voru á 1., 2., eða 3. starfsári í nokkrum tilvikum, sem og munur eftir faglegum bakgrunni peirra (námssviði/námsgrein í kennslu). Munur eftir skólastigi kom fram í fáeinum tilvikum en munur á svörum kennara eftir pví hvort peir höfðu fengið leiðsagnarkennara á sínu fyrsta ári eða ekki var ekki marktækt breytilegur. Svör nýliðanna sem fengu leiðsögn voru hins vegar marktækt önnur ef leiðsagnarkennari hafði svipaðan faglegan bakgrunn og nýliðarnir (kenndi sömu námsgrein eða námssvið) og pá kom fram marktækur munur á svörum peirra sem fengu leiðsögn eftir pví hve oft peir funduðu með leiðsagnarkennara.

Sú niðurstaða að leiðsögn virðist ekki hafa bein áhrif á svör pátttakenda í heild sinni pegar svör allra pátttakenda eru skoðuð kemur verulega á óvart, pegar horft er á niðurstöður erlendra rannsókna (Darling-Hammond, 2003; European Commission, 2010; Ingersoll, 2012; Jonson, 2008; Smith, 2015). Til pess að greina betur hvers vegna leiðsögnin hefur ekki pau áhrif sem við væntum skoðuðum við sérstaklega pætti í leiðsögninni hjá peim hópi sem fékk hana (49\%) og hvort breytileiki kæmi fram í svörum innan pess hóps. Fram kom að peir sem fengu tíða leiðsögn (hittu leiðsagnarkennara sinn oft) og voru með leiðsagnarkennara sem var með svipaðan bakgrunn svöruðu öðruvísi en peir sem funduðu sjaldan og fengu ekki leiðsagnarkennara með svipaðan bakgrunn. Stór hluti nýliðanna fundaði sjaldan með leiðsagnarkennara og hafði ekki leiðsagnarkennara sem kenndi sömu námsgrein/sama námssvið og nýliðinn. Pessir nýliðar mátu 
gagnsemi leiðsagnar mun minni en sá hluti peirra sem fundaði oft með leiðsagnarkennara og hafði leiðsagnarkennara með svipaðan kennslugrunn. Jákvæð áhrif leiðsagnar skiluðu sér pví ekki $\imath$ heild í svörum pátttakenda vegna pess að neikvæð áhrif vógu pau algerlega upp.

\section{Náms- og fagsvið leiðsagnarkennara}

Peir sem störfuðu í framhaldsskóla og fengu leiðsögn á sínu fyrsta ári voru mun líklegri til að fá leiðsagnarkennara sem hafði ápekkan bakgrunn (yfir 80\%) en grunnskólakennararnir (yfir $60 \%$ ). Pessi munur kemur ekki á óvart par sem minni áhersla er lögð á faggreinabundna kennslu á yngsta stigi og miðstigi grunnskóla en á unglingastigi eða í framhaldsskóla og getur verið erfitt að koma pví við að faglegur bakgrunnur nýliða og leiðsagnarkennara sé sambærilegur.

Nokkru munaði á mati nýliða á gagnsemi leiðsagnar eftir skólastigi. Nýliðar framhaldsskólanna gáfu gagnsemi yfirleitt einkunnina um 4,5-4,8 af 6 eftir pví hvaða páttur átti í hlut en nýliðar grunnskóla 4,0-4,6 fyrir sömu pætti. Pátttakendur töldu almennt mikilvægt að leiðsagnarkennari peirra hefði ápekkan bakgrunn og peir sjálfir en nýliðar í framhaldsskólum voru afdráttarlausari í peirri afstöðu, gáfu pví gildið 5,4 (á sex stiga kvarða) en grunnskólakennararnir 5,1. Dessar niðurstöður sýna að nýliðarnir telja pað skipta máli að leiðsagnarkennari peirra hafi svipaðan bakgrunn og pað endurspeglast jafnframt í mati peirra á gagnsemi leiðsagnarinnar. •að er til samræmis við niðurstöður úr erlendum rannsóknum pví í nýliðarannsóknum (Ingersoll, 2012) kemur fram að leiðsögn nýliða sé árangursríkust pegar hún kemur frá kennara sem kennir sömu námsgrein eða námssvið og nýliðinn. Pví má ætla að pátttakendur finni gagnsemi og öryggi í pví að fá leiðsögn frá peim sem pekkja vel til námsefnis og námskrár og aðstæðna sem nýliðar eru í og pví gott að leiðsagnarkennari geti miðlað af reynslu sinni til nýliða (Johnson, 2008). Enn fremur ætti pekking og reynsla af svipuðum aðstæðum að skapa skilyrði til samræðu sem byggist á gagnkvæmri pekkingu hlutaðeigandi á peim viðfangsefnum, námsefni og kennsluaðferðum sem hæfa best nemendum hverju sinni (Desimone o.fl., 2014). Samkvæmt niðurstöðum úr pessari rannsókn og erlendum rannsóknum (Desimone o.fl., 2014; Ingersoll, 2012; Jonson, 2008; Smith, 2015) ætti að huga að pví að velja leiðsagnarkennara fyrir nýliða sem hafa sama eða svipaðan bakgrunn og peir eða pekkja vel til kennslu í námsgrein eða á námssviði nýliðans.

\section{Mat á gagnsemi leiðsagnar}

Aðeins helmingur kennaranna hafði leiðsagnarkennara á sínu fyrsta ári og var hlutfallið sambærilegt í grunn- og framhaldsskólum, sem er svipað og hefur komið fram í íslenskum rannsóknum á nýliðum í grunnskólum (María Steingrímsdóttir, 2007). Sérstaka athygli vakti hve margir pátttakenda sem fengu leiðsögn sögðust aldrei hafa fundað formlega með leiðsagnarkennara sínum, eða rúmur fimmtungur. Alls sagðist rúmur priðjungur hafa fundað einu sinni í mánuði, sjaldnar eða aldrei. Óhjákvæmilegt er að setja spurningarmerki við gagnsemi leiðsagnar í pessum tilfellum. Samkvæmt fyrri rannsóknum á nýliðum hér á landi leita peir sjaldan eftir leiðsögn að fyrra bragði, og bera pví við að peir vilji ekki trufla ofurhlaðna kennara með pví að krefja pá svara við spurningum sem brenna á peim (Hildur Hauksdóttir, 2016; María Steingrímsdóttir, 2007). Pví má velta fyrir sér hvort peir nýliðar sem ekki hitta leiðsagnarkennara sinn leita til annarra kennara sér til stuðnings eða reyna að prauka af erfiðleika sem peir kunna að mæta í starfi án aðstoðar. Ingersoll (2012) sýnir fram á að pegar nýir kennarar fá litla aðstoð í upphafi eða peir eru látnir afskiptalausir komi pað niður á hæfni peirra, m.a. til að mæta fjölbreytilegum pörfum nemenda. Starf kennara felur í sér samstarf við aðra kennara og ætla má að peir fái úrlausn ákveðinna atriða á pann hátt. Tolhurst (2010) telur að slík leiðsögn geti leyst dagleg vandamál sem parfnast skjótra úrlausna en hún komi ekki í stað leiðsagnar frá menntuðum leiðsagnarkennara sem ræðir málin ítarlega við nýliðann. Hann telur hættu á pví að álag í starfi verði pessum kennurum erfitt og geti valdið peim óánægju með starfið, sem geti leitt til pess að peir hætti störfum eftir stuttan tíma. Í pessum tilfellum er vert að skoða hver tilgangur pess er að skipa leiðsagnarkennara sem aldrei hittir nýliðann og hver eigi að hafa eftirlit með peirri leiðsögn sem nýliðar fá innan skóla. 
Rúmur helmingur kennaranna fundaði hins vegar vikulega eða oftar með leiðsagnarkennara sínum. Desimone og félagar (2014) segja að formleg samskipti nýliða og leiðsagnarkennara ráði miklu um gagnsemi leiðsagnar að mati nýliða. Athyglisvert er að pegar tíðni formlegra funda nýliða og leiðsagnarkennara í rannsókninni er skoðuð kemur fram að nýliðar sem höfðu ekki leiðsagnarkennara með svipaðan bakgrunn og peir funduðu allir sjaldnar en vikulega með sínum leiðsagnarkennara. Pví er mikilvægt að hægt sé að koma pví pannig fyrir að slíkir leiðsagnarfundir séu fastsettir og peim sé gefinn góður tími. Mikilvægt er líka að undirbúa og nýta slíka fundi vel til samræðu og taka par fyrir ýmsar hliðar starfsins, ekki síður pær félagslegu og siðrænu (Ragnhildur Bjarnadóttir, 2015) en pær sem snúa að faglegum páttum starfsins. Enn fremur er mikilvægt að leiðsagnarkennarar fái undirbúning fyrir leiðsagnarhlutverkið, pví sýnt hefur verið fram á að leiðsögn sem veitt er af leiðsagnarkennurum sem fengið hafa menntun í að veita leiðsögn skilar betri árangri en peirra sem ekki hafa slíkan undirbúning fyrir starfið (Helleve o.fl., 2015). Munurinn komi helst fram í pví að peir sem eru vel undirbúnir fyrir leiðsagnarstarfið séu meðal annars meðvitaðri um ábyrgð sína á faglegri próun kennarans, átti sig betur á hvar leiðsagnar er pörf og séu færari um að ýta undir ígrundun peirra sem piggja leiðsögn (Helleve o.fl., 2015; Van Esch og Tillema, 2015).

Niðurstöður rannsóknarinnar sýna að svör peirra kennara sem fengu leiðsögn voru á ýmsan hátt breytileg hvað varðar kennslutengda pætti sem nýliðar eru oft í vanda með eftir tíðni formlegra leiðsagnarfunda. Peir sem funduðu vikulega eða oftar með leiðsagnarkennara gáfu gagnsemi leiðsagnarinnar marktækt hærri einkunn en peir sem funduðu sjaldnar. Par má nefna pætti eins og framkvæmd og próun kennslu og mat á vinnu nemenda, sem Ingersoll og Strong (2011) taka fram að sé einmitt nauðsynlegt að nýir kennarar fái góðan stuðning við á fyrstu starfsárum sínum.

Pessi tengsl voru jafnframt sýnileg í afstöðu kennara eða viðhorfum til ýmissa pátta í starfi sem tengjast upplifun peirra af starfsaðstæðum innan skólanna og geta haft áhrif á líðan peirra í starfi. Peim pykir til að mynda frekar en peim sem funda sjaldnar að skólanum sé umhugað um pá, að skólinn styðji almennt betur við pá í starfi og veiti peim stuðning pegar peir purfa á honum að halda. Peir telja enn fremur að fleiri samstarfmenn í skólanum hjálpi nýliðum í kennslu, styðji pá til að gera sitt besta í starfi og að leysa úr samskiptavanda við nemendur pegar við á, sem og öðrum erfiðleikum í tengslum við nemendur. Pessar niðurstöður falla vel að peim niðurstöðum Ingersoll (2012) að kennarar sem fá leiðsögn séu ánægðari starfsmenn og skuldbinding peirra við starfið sé meiri en peirra sem ekki njóta leiðsagnar.

Í niðurstöðunum kemur fram að stuðningur við nýliða einskorðast ekki við leiðsagnarkennara. Skólinn sem stofnun, stjórnendur og kennarar veita nýliðunum einnig ýmiss konar stuðning. Gjarnan er talað um formlegan stuðning í höndum leiðsagnarkennara og hins vegar óformlegan stuðning frá öðrum innan skólans, stjórnendum og samkennurum (Desimone o.fl., 2014; Johnson og Birkeland, 2003). Slíkur stuðningur hefur verið kallaður óformleg leiðsögn og er talinn skipta máli fyrir nýliða með tilliti til pess hvernig peim vegnar á fyrstu árum í starfi. Segja má að formlegur og óformlegur stuðningur við nýliða í starfi endurspegli styðjandi skólamenningu (Cherubini, 2009). Hér á landi hefur formleg leiðsögn verið illa skilgreind innan skólanna og er jafnvel tilviljunarkennd (María Steingrímsdóttir, 2007 og 2010). Af peim sökum má ætla að munur á formlegri og óformlegri leiðsögn í skólum hér sé ekki eins afgerandi og lýst er í erlendum rannsóknum á leiðsögn (Smith, 2015), og að nýliðar geri ekki mikinn greinarmun á pessu. Í niðurstöðum okkar vekur pó athygli að pegar óformlegur stuðningur er fyrir hendi í skólunum er pað stuðningsnet í heild péttofnara pegar formleg samskipti nýliða og leiðsagnarkennara eru einnig til staðar og eru tíð.

Rannsóknin sýnir að leiðsögnin skiptir máli en pað fer eftir pví hvernig hún er, ekki hvort hún er til staðar. Hún skilar góðum áhrifum pegar vel er staðið að henni en niðurstaðan hér er sú að ekki sé nægilega vel staðið að henni og margir telji hana pví gagnslitla. 


\section{Hætta á brotthvarfi}

Rúm 11\% kennaranna segjast hafa leitað með skipulegum hætti að nýju starfi og litlu fleiri (15\%) segjast munu hætta að starfa við skóla sinn finni peir annað starf. Pá segist hátt í priðjungur kennaranna velta pví alvarlega fyrir sér að skipta um starf. Áhugavert er að sjá að pað er ekki munur á hugleiðingum kennara um að hverfa úr starfi eftir skólastigi, starfsaldri, tíðni leiðsagnarfunda eða faglegum bakgrunni leiðsagnarkennara peirra. Niðurstöðurnar sem við höfum rætt hér að framan er varða formlegan og óformlegan stuðning virðast pví ekki tengjast pví að kennarar hugsi sér til hreyfings í starfi eða úr starfi. Đað er gagnstætt niðurstöðum annarra rannsókna sem benda til pess að markviss stuðningur á fyrsta ári kennara vinni gegn pví að kennarar hverfi frá starfi (Bartel, 2005; Darling-Hammond, 2003; European Commission, 2010; Helgi Eiríkur Eyjólfsson og Stefán Hrafn Jónsson, 2017; Ingersoll, 2012; Ingersoll og Strong, 2011). Etla mætti að styðjandi skólamenning eins og nýliðar virtust upplifa hefði áhrif á hugleiðingar beirra um að hætta í starfi og pví kemur okkur á óvart að slík tengsl skyldu ekki mælast.

Hér má einnig hugleiða hvers konar stuðningur er í boði innan skólanna fyrir nýliða og hvort hann getur haft áhrifá á störf peirra og viðhorf til starfsins. Mögulegt er að peir nýliðar sem hafa upplifað lítinn stuðning hafi pegar horfið úr starfi, pað vitum við ekki nema með pví að ná til peirra sem hafa hætt störfum. Pá kann að vera að sú leiðsögn sem er í boði styðji nýliðana ekki nægilega vel og hafi ekki ætluð áhrif á hugleiðingar nýliðanna um að hverfa frá starfi. Fram hefur komið að hér á landi er leiðsögn og stuðningur við nýliða ómarkviss og snýr einkum að praktískum páttum starfsins (sjá t.d. Hildi Hauksdóttur, 2016; Maríu Steingrímsdóttur, 2007). Pessi rannsókn staðfestir petta að pví leyti að rúmur priðjungur pátttakenda hitti leiðsagnarkennara sinn aðeins einu sinni í mánuði eða aldrei og pess vegna er ekki mikils að vænta af pess konar leiðsögn. Einnig kann að vera að aðrir pættir en peir sem við skoðuðum stuðli frekar að pví að kennarar láti af kennslu, svo sem álag, agavandi, aðbúnaður og tækifæri til endurmenntunar - sem við tökum ekki fyrir í pessari grein.

\section{Lokaord}

Í pessari grein hafa atriði í sambandi við gagnsemi leiðsagnar fyrir nýliða í kennslu, að peirra mati, verið dregin út úr stærri rannsókn á nýliðum. Aðeins tæplega helmingur pátttakenda í rannsókninni fékk sérstaklega skipaðan leiðsagnarkennara sem átti að sjá um formlega leiðsögn nýliðans. Einkum má greina tvær afgerandi niðurstöður um mat nýliðanna á gagnsemi leiðsagnar. Annars vegar er ótvírætt að nýliðar meta gagnsemi leiðsagnar meiri ef hún er veitt af leiðsagnarkennara sem kennir sömu námsgrein eða er kennari á sama námssviði/stigi og viðkomandi nýliði. Dví ætti að huga vel að pessu atriði pegar nýliða er úthlutað leiðsagnarkennara. Í öðru lagi virðist ljóst að eftir pví sem samband leiðsagnarkennara og nýliða er meira og fundir tíðari, peim mun meiri telja peir gagnsemi leiðsagnarinnar. Раð bendir eindregið til pess að leggja eigi áherslu á að skapa leiðsagnarkennurum tíma og svigrúm til að sinna leiðsögn, að peir geti haft fastan fundatíma með nýliðum og purfi mögulega ekki að sinna leiðsögn ofan á fullt starf. Augljóst er að leiðsögn skiptir nýliða máli varðandi mikilvæga pætti í kennarastarfinu og pví parf að taka til athugunar að ekki er nóg að skipa einhvern til leiðsagnar; pað parf að fylgja pví eftir að peir sem skipaðir eru sinni pví starfi sem peir eru skipaðir til og hafi góða pekkingu á hlutverki sínu sem leiðsagnarkennarar. Peir purfa að geta stutt sem best pá sem hefja störf við kennslu og sá stuðningur parf að hafa pau áhrif á störf peirra og viðhorf til starfsins að pað leiði til pess að peir ílengist í starfi og nái góðum tökum á kennarastarfinu.

Pótt niðurstöður rannsóknar okkar bendi ekki til pess að tengsl séu milli pessara pátta og hugleiðinga pátttakendanna um að hverfa frá starfi skiptir góður stuðningur við pá verulegu máli og ætti að vera órjúfanlegur páttur í menningu hvers skóla. 


\begin{abstract}
It is believed that the first year of teaching has a gradual impact on teachers' efficiency, satisfaction and intention to stay at work (Bartell, 2005; Darling-Hammond, 2003; Feiman-Nemser, 2003; Ingersoll and Strong, 2011). It is also believed that insufficient support for the first year teachers can reduce their ability to fulfil students' various needs (Ingersoll, 2012 There is a clear link between a good support system for first-time-teachers, improved teaching methods and student learning outcomes, which underlines the importance of providing teachers with good support in their first year of teaching (Ingersoll and Strong, 2011).
\end{abstract}

The article discusses the Icelandic data of the Nordic research project NORDMENT, on new qualified teachers' attitude towards work, and on how well they are doing in teaching in compulsory and upper secondary schools. The research was conducted in collaboration with scholars from the universities of Oslo, Gothenburg, Aarhus and Turku. The goal was to study how school support, school management and school structure influence the way new qualified teachers adapt to teaching, how they assess their own skills and the circumstances that schools offer them.

Participants were teachers during the first three years of teaching or those who had completed three years of work. The study was quantitative. A uniform questionnaire was used, translated and localized, in all of the participating countries. The questionnaire was sent electronically to 280 teachers in Iceland, one third of whom were in upper secondary schools and two thirds in compulsory schools. The results are based on answers from 239 teachers (response rate was 85.4\%).

The main objective of this article is to provide insight into the data that deals with formal and informal support for new qualified teachers at work. The article focuses on answers to questions about school support, school management and synergies with their work, as well as their perception of how far their school and colleagues are concerned about their well-being at work. It looks at how formal the guidance is for recruits in primary and secondary schools in their first year of work, whether there is a link between formal guidance, professional background of the mentor, frequency of formal meetings with the mentor and the newcomers' evaluation of practical guidance regarding various aspects of the participants' work.

The main results indicate that newcomers usually experience good support from the school and its administrators, as well as their colleagues. The support did not depend on whether they received formal mentoring in their first year of work. However, those who received formal mentoring and had formal meetings with their mentor once a week or more, often experienced significantly more informal support within the school than those who did not. Evaluation of the utility of mentoring also relates to the frequency of formal meetings between newcomers and their mentors.

Nearly half of the newcomers received mentoring during their first year of teaching. There was no significant difference between the responses in the study as to whether newcomers received mentoring in the first year or not, but when the guidance was examined further, such relationships were revealed. Mentoring seemed to affect the practice and well-being of newcomers if it was provided by teachers who had a similar professional basis as the newcomer, and if they met regularly during the mentoring period. The findings indicate that there is a gap in formal communication between newcomers and mentors during the first year of employment. About one third of the newcomers only met formally with their mentor once a month or less, of whom about one-fifth never met formally. About half, however, had formal meetings with their 
mentor once a week or more often, and their answers were often different from those who had fewer formal meetings. The frequency of formal meetings and the professional background of the mentors were the variables that had the strongest connection with job satisfaction and experience of support for school work.

The new teachers were asked whether they had thought about or intended to quit work, and whether there was a link between these thoughts and the formal and informal support they received. About a third of the participants had thought about quitting, but only one tenth had made a real effort to seek another job. However, there was no appreciable link between these thoughts and the support they received.

Key words: Novice teachers, informal mentoring, formal mentoring, beginning teacher attrition.

\section{Um höfunda}

María Steingrímsdóttir (maria@unak.is) er dósent við kennaradeild hug- og félagsvísindasviðs Háskólans á Akureyri. Hún lauk kennaraprófi frá Kennaraskóla Íslands 1972 og starfaði sem grunnskólakennari um árabil. María lauk meistaraprófi í menntunarfræðum með áherslu á stjórnun, frá kennaradeild Háskólans á Akureyri árið 2005. Rannsóknir hennar beinast að nýliðum í kennarastarfi, starfstengdri leiðsögn, starfspróun kennara og kennaramenntun.

Guðmundur Engilbertsson (ge@unak.is) er lektor við kennaradeild hug- og félagsvísindasviðs Háskólans á Akureyri. Hann hefur lokið B.Ed.-prófi í kennarafræði og M.Ed.-prófi í menntunarfræði við HA og er doktorsnemi í menntavísindum við HÍ. Guðmundur hefur starfað við grunn- og tónlistarskóla og hefur um árabil verið ráđgjafi í próunarstarfi í læsi. Helstu viðfangsefni hans í kennslu og rannsóknum lúta að orðaforða, læsi til náms og náms- og kennslufræði.

\section{About the authors}

María Steingrímsdóttir (maria@unak.is) is associate professor at the Faculty of Education in the School of Humanities and Social Sciences at the University of Akureyri. She graduated as a teacher from the Iceland University of Education in 1972 and has a long teaching career in elementary schools. María completed M.Ed. degree, specializing in management, from the Faculty of Education at the University of Akureyri in 2005. Her main research interests are the mentoring of new teachers, teacher education, and teachers' professional development.

Guðmundur Engilbertsson (ge@unak.is) is an assistant professor at the Faculty of Education in the School of Humanities and Social Sciences at the University of Akureyri. He holds a B.Ed.-degree in Education from the University of Akureyri, M.Ed.-degree in Educational studies from the University of Akureyri and is currently a doctoral student (Ph.D) at the University of Iceland. His teaching and research interest includes vocabulary learning and teaching, literacy for learning and learning and teaching methods. 


\section{Heimildir}

Bartell, C. (2005). Cultivating high-quality teaching through induction and mentoring. Thousand Oaks: Corwin Press.

Darling-Hammond, L. (2003). Keeping good teachers: Why it matters what leaders can do. Educational Leadership, 60(8), 6-13.

Darling-Hammond, L. (2006). Constructing 21st- century teacher education. Fournal of Teacher Education, 57(3), 300-314. https://doi.org/10.1177/0022487105285962

Darling-Hammond, L., Wei, R. G. Andree, A. Richardson, N. og Orpjanos, S. (2009). Professional learning in the learning profession: A status report on teacher development in the United States and abroad. Stanford, CA: National Staff Development Council and the School Redesign network at Stanford University

Desimone, L. M., Hochberg, E. D., Porter, A. C., Pollikoff, M. S. Schwartz, R. og Johnson, L. J. (2014). Formal and informal mentoring: Complementary, compensatory or consistent? Fournal of Teacher Education, 65(2), 88-110. https:// doi.org/10.1177/0022487113511643

Cherubini, L. (2009). New teacher's perceptions of induction: Insights into principled practices. The Alberta fournal of Educational Research, 55(2), 185-198. Sótt af http://www.iier.org.au/iier19/cherubini.html

European Commission. (2010, apríl). Developing coherent and system-wide induction programmes for beginning teachers: A handbook for policymakers. Brussel: Höf.

Feiman-Nemser, S. (2003). What new teachers need to learn. Educational Leadership, 60(8), 25-29.

Fransson, G. og Gustafsson, C. (2008). Newly qualified teachers in northern Europe-comparative perspectives on promoting professional development. Gävle: Gävle University.

Hammerness, K., Darling-Hammond, L. og Brandsford, J. (2005). How teachers learn and develop. Í L. Darling-Hammond og J. Brandsford (ritstjórar), Preparing teachers for a changing world: What teachers should learn and be able to do (bls. 358-389). San Francisco: Jossey-Bass.

Heikkinen, H. L. T., Joikinen, H. og Tynjälä, P. (ritstjórar). (2012). Peer group mentoring for teacher development. London: Routledge.

Helgi Eiríkur Eyjólfsson og Stefán Hrafn Jónsson. (2017). Skýrsla til starfshóps um nýliðun og bett starfsumhverfi grunnskólakennara i Reykjavík: Könnun á meðaltal útskriftarárganga úr kennaranámi HÍ/KHÍ og HA árin 2000-2012. Reykjavík: Háskóli Íslands, Félagsvísindasvið (Skýrsla).

Helleve, I., Danielsen, A. G. og Smith, K. (2015). Does mentoring-education make a difference? Í H. Tillema, G. J. van der Westhuizen og K. Smith (ritstjórar), Mentoring for learning: "Climbing the mountain" (bls. 313-332). Rotterdam: Sense Publisher.

Hildur Hauksdóttir. (2016). Allir á hlaupum. Upplifun nýliða i stétt framhaldsskólakennara (óútgefin meistararitgerð). Háskólinn á Akureyri: Akureyri.

Hobson, A., Ashby, P., Malderez, A. og Tomlinson, P. D. (2009). Mentoring the beginning teacher: what we know and what we don't. Teaching and Teacher Education, 25(1), 207-216. https://doi.org/10.1016/j.tate.2008.09.001

Ingersoll, R. (2012). Beginning teacher induction: What the data tell us. Phil Delta Kappan, 93(8), 47-57. https://doi. org/10.1177/003172171209300811

Ingersoll, R. M. og Strong, M. (2011). The impact of induction and mentoring programs for beginning teachers: A critical review of the research. Review of Educational Research, 81(2), 201-233. https://doi.org/10.3102/003465431 1403323

Jonsson, K. (2008). Being an effective mentor: How to help beginning teachers succeed. Thousand Oaks: Corwin.

Johnson, S. M. og Birkeland, S. E. (2003). Pursuing a "sense of success": New teachers explain their career decisions. Amercan Education Research fournal, 40(3), 581-617.

Kemmis, S., Heikkinen, H. L.T., Fransson, G., Aspfors, J. og Edwards-Groves, C. (2014). Mentoring of new teachers as a contested practice: Supervision, support and collaborative self-development. Teaching and Teacher Education, 43, 154-164. https://doi.org/10.1016/j.tate.2014.07.001

Le Maistre, C. og Paré, A. (2010). Whatever it takes: How beginning teachers learn to survive. Teaching and Teacher Education, 26(3), 559-564. https://doi.org/10.1016/j.tate.2009.06.016

Lög um menntun og ráđningu kennara og skólastjórnenda við leikskóla, grunnskóla og framhaldsskóla nr. 87/2008.

María Steingrímsdóttir. (2007). Ofsalega erfitt og rosalega gaman. Reynsla nýbrautskráðra kennara af fyrsta starfsári. Uppeldi og menntun, 16(2), 9-27.

María Steingrímsdóttir. (2010). „Nú veit maður ef til vill út á hvað starfið gengur“: Hvað segja kennarar eftir fimm ár í starfi? Uppeldi og menntun, 19(1-2), 71-88.

OECD (European Commission). (2014). The OEGD teaching and learning international survey (Talis) - 2013. https:// doi.org/10.1787/9789264196261 
Ragnhildur Bjarnadóttir. (2015). Leiðsögn: Lykill að starfsmenntun og skólapróun. Reykjavík: Háskólaútgáfan.

Russel, M. L. og Russell, J. A. (2011). Mentoring relationships: Cooperating teachers' perspectives on mentoring student interns. Professional Educator, 35(1), 16-35. https://doi.org/10.4236/ape.2016.62012

Smith, K. (2015). Mentoring: A profession within a profession. Í H. Tillema, G. J. van der Westhuizen, og K. Smith (ritstjórar), Mentoring for learning: "Climbing the mountain" (bls. 283-298). Rotterdam: Sense Publishers.

Smith, K. og Ulvik, M. (ritstjórar). (2010). Veiledning av nye larere. Nasjonale og internasjonale perspektiver: Olso: Unversitetforlaget.

Smith, T. M. og Ingersoll, R. M. (2004). What are the effects of induction and mentoring on beginning teacher turnover? American Educational Research fournal, 4(3), 681-714. https://doi.org/10.3102\%2F00028312041003681

Sundli, L. (2007). Mentoring - a new mantra for education? Teacher and Teaching Education, 23(2), 201-214. https://doi. org/10.1016/j.tate.2006.04.016

Tolhurst, J. (2010). The essential guide to coaching and mentoring (2. útg.). London: Pearson Education.

Ulvik, M., Smith, K. og Helleve, I. (2009). Novice in secondary school - the coin has two sides. Teaching and Teacher Education, 25(6), 835-842. https://doi.org/10.1016/j.tate.2009.01.003

Van Esch, G. og Tillema, H. (2015). The learning potential of learning. Í H. Tillema, G. J. van der Westhuizen og K. Smith (ritstjórar), Mentoring for learning: "Climbing the mountain" (bls. 155-179). Rotterdam: Sense Publisers.

UNESCO Institute of Statistics. (2009). Projecting the global demand for teachers: Meeting the goal of universal primary education by 2015. Technical Paper NO. 3 UNESCO Institute for Statistics. Sótt af http://unesdoc.unesco.org/images/0018/001863/186397e.pdf

María Steingrímsdóttir og Guðmundur Engilbertsson. (2018).

Mat nýliða á gagnsemi leiðsagnar í starfi kennara.

Netla - Veftímarit um uppeldi og menntun. Menntavísindasvið Háskóla Íslands.

Sótt af http://netla.hi.is/greinar/2017/ryn/03

DOI: https://doi.org/10.24270/netla.2018.3 